YEARBOOK

of ANTITRUST

and REGULATORY

STUDIES

www.yars.wz.uw.edu.pl
Peer-reviewed scientific periodical, focusing on legal and economic issues of antitrust and regulation. Creative Commons Attribution-No Derivative Works 3.0 Poland License.

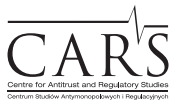

Centre for Antitrust and Regulatory Studies, University of Warsaw, Faculty of Management www.cars.wZ.uw.edu.pl

\title{
Commitment Procedure under Serbian Competition Act
}

\author{
by
}

Srđana Petronijević and Zoran Šoljaga*

\section{CONTENTS}

I. Preliminary remarks

II. Introduction of commitment procedure into Serbian Competition Act

1. Legal framework

2. Deficiencies in the transposition of EU instruments

3. How and when parties learn what constitutes a competition concern in individual cases

4. Time limit for submitting observations on the market test

5. Inability to impose fines in case of non-compliance with commitments

6. Types of antitrust investigations allowing for the application of the commitment procedure

7. Resolution halting proceedings is not the final act of the Commission

III. Practice in the application of commitment procedure in proceedings before the Commission

IV. Final remarks

Key words: commitment; competition law; Serbia

JEL: K21

* Srđana Petronijević, Partner with Moravčević, Vojnović and Partners in cooperation with Schoenherr, head of competition practice; s.petronijevic@schoenherr.rs. Zoran Šoljaga, Attorney at law, Moravčević, Vojnović and Partners in cooperation with Schoenherr; z.soljaga@ schoenherr.rs. Article received: 10.08.2017; accepted: 12.09.2017. 


\section{Preliminary remarks}

The Serbian Competition Act $^{1}$, which has been in force since November 2009, was amended in 2013 in order to improve the effective enforcement of competition rules by the Commission for Protection of Competition (hereinafter, the Commission or Competition Commission), and to further harmonise national regulations with the EU acquis in the area of protection of competition. The 2009 Competition Act (hereianfter, the Act), which introduced some modern competition protection concepts into the Serbian legal system, had certain deficiencies which hindered the practical application of the statute and, consequently, effective enforcement by the Commission.

In addition to the existing provisions of the Act, the legislator introduced a novelty that will, beyond any doubt, produce considerable effects on the Commission's actions in deciding on competition infringement cases. The novelty concerns the introduction of the so-called commitment procedure, which allows the Commission to close a competition infringement case by accepting commitments offered by the undertakings concerned, without establishing whether there has been an infringement. The instrument has turned out to be exceptionally effective in closing proceedings before the competition authorities of the EU and the Member States.

The concept ensures procedural economy, as the Commission need not to establish the existence of the infringement, which makes the proceedings shorter and more appropriate particularly for more dynamic sectors of the economy, while the actual concerns about the market are effectively addressed. Further, the concept is favourable for the undertakings concerned as it enables them to propose measures they believe will resolve suspicions of competition law infringement, thus bringing proceedings to an end without finding the infringement, allowing them to avoid high fines and potential actions for damages.

\section{Introduction of commitment procedure into Serbian Competition Act}

\section{Legal framework}

The amendments to the Competition Act modify Article 58 of the Act, by regulating the stay of proceedings; they stipulate that proceedings may be stayed in case a party makes certain commitments. Pursuant to the relevant Article:

1 The Competition Act (Official Gazette RS, nos. 51/09 and 95/2013). 
"the Commission may by a resolution stay antitrust proceedings aimed at imposing remedies referred to in Article 59 of the Act (structural and behavioural measures), where a party, based on the content of the resolution initiating proceedings or facts established in the proceedings, offers commitments it is prepared to make on a voluntary basis to meet any competition concerns, along with the terms and the time-limits for implementing the remedy".

The party may submit its proposal for commitments no later than the date of receipt of the Statement referred to in Article 38(2) of the Act. The Commission must publish the main elements of the proceedings and a concise summary of the offered commitments and invite all interested third parties to submit their observations, positions or opinions in writing within 20 days. Paragraph 5 of this Article stipulates that the Commission is not bound by a proposal of commitments.

It is within the remit of the Commission Council to adopt resolutions staying proceedings, which must contain the remedies, terms and time limits for implementation, and the party's obligation to provide evidence of compliance with its commitments. Further, the amendments set out that proceedings will be resumed in case certain circumstances occur within 3 years.

\section{Deficiencies in the transposition of EU instruments}

The introduction of modern competition law concepts and the harmonisation with the EU Acquis are not only one of Serbia's international obligations, but also contribute to a better regulation of the Serbian market and more effective enforcement by the Commission. The introduction of the commitment procedure is an important step towards more effective handling of cases before the Commission, which will allow the parties to respond to Commission's objections within shorter time limits and bring their behaviour on the market into compliance with the competition rules, while enabling the Commission to resolve specific competition concerns more swiftly and focus on priority cases.

\section{How and when parties learn what constitutes a competition concern in individual cases}

Unfortunately, the Act does not fully transpose all the elements of the commitment procedure from the EU law, while some of the provisions introduced by the legislator into the Serbian competition law lack precision. The provisions in Article 58 could produce converse effects than those aimed 
for. The provision setting out that a party may only offer commitments based on the allegations in the resolution initiating the proceedings does not serve the purpose of effective application of commitments. The resolution initiating proceedings mainly contains a short description of the allegations in the complaint or information the Commission collected before it opened proceedings. It does not contain the Commission's assessment of market disruptions as, at that time, the Commission does not have sufficient information on the market that would allow it to make any kind of assessment, other than a reasonable assumption of the existence of a competition infringement. When applying the European institutions' case law, which holds that the European Commission is obliged to fully investigate and clearly identify its competition concerns, the national competition authority must have access to the relevant data and must adequately analyse it. In this respect, the provision stipulating that commitments and a stay of proceedings may be proposed based on the resolution is contrary to the EU case law, particularly in view of the fact that the Competition Act does not regulate the pre-investigation stage, so that the Commission for the most part has only limited data available at the very beginning of the proceedings.

Alternatively, a party may also offer commitments "on the basis of facts found in the proceedings". However, the issue here is that, in proceedings before the Commission, the parties are not informed of the facts found in the proceedings until they have received the statement of objections, which is provided at the end of the investigation and whose provision, pursuant to Article 58(2), is the final time limit for the parties to offer commitments. This contradiction/lack of logic is a consequence of the "copying" of EU law provisions without taking into account the previous rules applying to proceedings conducted before the national authority, or the absence of the pre-investigation stage, or indeed other EU law elements, in Serbian law. The Competition Commission's practice does not know the so-called "preliminary assessment" or State of Play meetings, which are a signal to the parties that the European Commission is ready to engage in discussions on the application of Article 9 of the EU Regulation. The parties are not familiarised with the Commission's assessments and the tests carried out during the proceedings until they receive the statement of objections.

The Commission will evidently have to harmonise its practices with this statutory power and enable parties to familiarise themselves with the Commission's assessment of the action that is the subject matter of an investigation, so that they could submit a proposal for commitments. 


\section{Time limit for submitting observations on the market test}

The Competition Commission must publish a concise summary of the offered commitments and of the main elements of the proceedings. This allows all the undertakings concerned to partake in the assessment of the offered commitments, making the proceedings transparent and enabling the Commission take into account the positions of undertaking concerned and of expert bodies. Since practice has shown that Article 9 of the EU Regulation is frequently applied in regulated sectors of the economy such as telecommunications and energy, it is essential for the Commission's decision-making process and effective implementation of commitments to consult the competent regulatory bodies and institutions. What could have a restrictive effect on the Commission's actions is the statutory time limit of 20 days to submit observations and opinions concerning the published summary of offered commitments. The time limit is considerably shorter than that provided for under the EU Regulation, which leaves the third parties a minimum of one month to comment (Article 27(4) of the EU Regulation). Since it is a statutory time limit, the Commission may not extend it and will be largely restricted in gathering high quality observations and opinions concerning the offered commitments, particularly when in comes to structural remedies, which may have significant effects on the functioning of the relevant market.

\section{Inability to impose fines in case of non-compliance with commitments}

The grounds for re-opening proceedings correspond to those in Regulation $1 / 2003$, but the Commission is not authorised to impose fines in case of noncompliance with a commitment made. Conversely, the European Commission may impose a fine up to $10 \%$ of a party's total annual turnover in case of non-compliance with a commitment made binding by a decision pursuant to Article 9 of the Regulation, or a non-compliance penalty of $5 \%$ of a party's daily turnover for each day of delay, to compel the party to comply with its commitments made binding by a decision. The only remedy available to the Competition Commission, is to, in fixing a competition infringement fine imposed after the re-opening of proceedings, take the party's non-compliance as an aggravating circumstance and impose a higher fine. In this sense it is necessary to amend the existing Competition Infringement Fines Decree and Guideline, specifically the part defining the criteria for imposing fines, by introducing a new criterion pertaining to non-compliance with commitments 
made binding by a resolution staying proceedings. The existence of a direct fine for non-compliance with commitments would have a deterrent effect on the parties contemplating non-compliance. In previous EU institution practices the only fine for non-compliance with commitments was imposed on Microsoft, in the amount of EUR 561 million, in a case of a restriction of competition in the choice of a web browser. Joaquin Almunia, the former European Commissioner for Competition, following the Microsoft decision, stated that: "If companies agree to offer commitments which then become legally binding, they must do what they have committed to do or face the consequences - namely, the imposition of sanctions".

\section{Types of antitrust investigations allowing for the application of the commitment procedure}

Finally, the legislator failed to restrict the application of commitments, i.e. to detail in which types of proceedings it is inappropriate to adopt the resolution staying proceedings. Unlike Serbia's legal framework, the EU Regulation and subsequent EU case law imply that commitment decisions are not appropriate in cases where the Commission intends to impose a fine, i.e. in hard-core cartel cases. Pursuant to the current version of the Competition Act, even in cartel cases parties may offer commitments, which the Commission is obliged to consider although it is allowed to dismiss them. This additionally lengthens proceedings and creates a burden on the Commission.

The Commission attempted to overcome this deficiency by adopting the Opinion on the implementation of Article 58 of the Competition Act ${ }^{2}$. In it, the Commission states that the application of Article 58 of the Competition Act is not appropriate in most serious competition infringement cases, such as cartel cases. The Commission refers to the relevant European regulations and case law, invoking the obligation under the Stabilisation and Accession Agreement, entered into between Serbia and the EU, to interpret competition rules in accordance with EU legislation and practices. As stated in the Opinion, the Commission received a large number of petitions for a stay of proceedings in horizontal agreement cases, and the purpose of the Opinion was to deter parties in such cases from submitting petitions for a stay of proceedings. Although the Opinion has no legal effects, it was a valid initiative by the Commission to correct the legislative omission.

\footnotetext{
2 http://www.kzk.gov.rs/kzk/wp-content/uploads/2015/05/misljenje-primena-clana-58-zakonao-zastiti-konkurencije-13052015.pdf (2.11.2017).
} 


\section{Resolution staying proceedings is not the final act of the Commission}

Contrary to the EU practice, a resolution staying proceedings is a procedural document and does not close administrative proceedings. Therefore, the commitment decision in Serbia is not the final act in a given proceeding. Specifically, proceedings may continue for up to three years in case of (i) a major change in the circumstances on which the resolution was based; (ii) a party fails to comply with its commitments within the fixed time limit or fails to submit evidence of compliance; and (iii) the resolution is found to be based on incorrect, untrue, incomplete data provided by a party during the proceedings. After a three-year period, the Commission should, according to the rules of administrative proceedings, adopt a resolution staying proceedings, which would constitute the final administrative instrument. The consequence of such a solution is a limited duration of the commitments of up to three years.

As the resolution staying proceedings is a procedural document, it may not be appealed. Further, it is questionable whether an appeal is allowed to the Administrative Court, which is competent for deciding on the lawfulness of the Commission's final instruments. In the previous court practice, procedural resolutions were not subject to court control. If this resolution is treated the same way, this could result in a failure to create case law or ensure control over the Commission's work and adequate application of the commitment procedure in Serbia. Evidently the number of appeals against such decisions is small, but this obstacle additionally hampers the development of competition case law in Serbia. In addition, third parties have no rights in proceedings before the Commission and the Administrative Court has so far dismissed third party appeals against Commission decisions, including complaints concerning suspected infringements of competition rules, on grounds of lack of capacity to act as a party in proceedings. Appeals should be allowed against resolutions staying proceedings, which must be adopted within three years, provided that the commitments have been complied with.

\section{Practice in the application of commitment procedure in proceedings before the Commission}

The Commission has adopted three resolutions staying proceedings since 2013. All three proceedings involved investigations of a suspected abuse of 
dominant position, interestingly all of them in state-run companies, i.e. public enterprises ${ }^{3}$.

The first decision was adopted shortly after the 2013 amendments to the Competition Act entered into force. In the Telekom 4 case, the Commission investigated the existence of (i) margin squeeze; (ii) price discrimination; (iii) tying; and (iv) unfair trading conditions on the wholesale market for ADSL broadband internet access. The proceeding lasted 3 years, until in late 2014 Telekom offered commitments, which were accepted by the Commission following a market test. Although the Commission did not, in the rationale of its resolution, elaborate on the competition concerns relating to the relevant infringements, the party offered a commitment for each individual infringement. The resolution defines the remedies and the time limit for complying with the commitments, which was set at two years as of the adoption of a decision in the case at hand. The only observation on the market test was given by a direct competitor of Telekom, requesting, among other, that the Commission apply the Reasonably Efficient Operator test, instead of the Equally Efficient Operator test, to assess margin squeeze, and that it impose stricter commitments on the company. The Commission took into account the competitor's observations, but did not accept them, invoking the principle of proportionality.

The second decision was adopted in a proceeding against JP Železnice Srbije involving a suspected abuse of dominance. The Commission investigated a suspected abuse of dominant position in the railway infrastructure market with foreclosure effects. The decision sets out as many as 34 commitments the party must comply with within three years. Most commitments involve the adoption of internal rulebooks and other bylaws, with the consent of the Government, to regulate railway infrastructure management. Hence, these are mainly regulatory commitments. The third decision staying proceedings was adopted in a case against JP Infostan Beograd. In this proceeding, the Commission investigated abuse of dominance by Infostan, which allegedly charged apartment insurance costs on behalf of an insurance company,

3 Although the Commission adopted all three decisions in proceedings against state-run, i.e. public enterprises, this should not lead to a premature conclusion that such companies are privileged in proceedings before the Commission. Specifically, the highest fine imposed so far in Serbia was EUR $3 \mathrm{mln}$ at the end of last year to the state-run company EPS Distribucija, a power distribution system operator. The proceeding was an example of a standard commitment decision, as it involved an abuse of dominance case - application of dissimilar conditions to equivalent transactions - which lasted a short time and, according to the allegations in the rationale, did not produce significant effects on the market. However, the case ended with an infringement decision.

4 http://www.kzk.gov.rs/kzk/wp-content/uploads/2014/11/Zakljucak-o-prekidu-postupkapokrenutog-protiv-Preduzeca-za-telekomunikacije-Telekom-Srbija-ad-Beograd.pdf (2.12.2017). 
thus bringing it into a favourable position relative to its competitors on the insurance market. In both these cases, unlike the Telekom case, the rationale of the resolutions do not indicate the Commission's competition concerns. They do not sufficiently substantiate either the definition of the relevant markets or the actions subject to proceedings. Further, they do not list the evidence collected or the procedural actions taken in order to establish the facts. Further, it remains unclear after an analysis of these cases at what time the parties decided to offer commitments, since, as mentioned above, the Commission's practice does not include State of Play meetings or a preliminary assessment, unlike in the EU enforcement regime. It remains unknown at what time in a proceeding before the Commission the parties should offer commitments. Finally, in the latter two cases there were no third party observations or proposals concerning the market test, which may imply that, unlike in the Telekom case, the actions subject to Commission investigation were not significant enough for the undertakings concerned.

\section{Final remarks}

The Commission's competence to adopt resolutions staying proceedings, provided for in Article 58 of the Competition Act, will contribute to the application of competition rules and efficiency of the proceedings before the Commission. However, several omissions were made in the transposition of the provision in Article 9 of the EU Regulation.

Article 58(5) of the Competition Act stipulates that the Commission is not required to accept commitments offered, i.e. that it has discretion in deciding on the proposals submitted by parties. In order to, on the one hand, ensure compliance with the principles of legal certainty, and on the other hand, avoid the overburdening of the Commission with petitions filed based on this Article, the Commission must adopt more detailed guidelines for proceeding on such cases. Unfortunately, this will not allow it to remedy the omission the legislator made by failing to provide for a possibility to impose a fine on a party not complying with the commitments it made. This omission could present a considerable issue in the application of the concept, particularly since the parties could view it as a means to protract proceedings. Specifically, the parties are not at a risk of being subject to high fines in case of failure to comply with their commitments, but only face the risk of re-opening of proceedings, whose time and manner of closure are unknown. In order to prevent such a scenario, the Commission will have to put in place an effective mechanism for the control of compliance with commitments. There are 
several manners in which competition authorities may control compliance with commitments, such as acting on their own initiative, regulatory control, control by undertakings concerned or regular reports submitted by parties to the proceedings. After it imposed the fine on Microsoft, the European Commission launched an initiative to improve the commitments compliance monitoring system, as it was established that its previous practice had certain deficiencies. Regardless of the method of monitoring, this will be an additional burden on the Commission's specialist service, which already operates with limited capacities. It is to be expected that the Commission will, in most cases, rely on complaints filed by third parties, the competitors of the party having made commitments, alleging non compliance, in order to make its capacities available for other priorities. In order to efficiently implement the procedure under Article 58, the Commission will have to make the procedure for the adoption of resolutions staying proceedings as transparent as possible and find a way for all the undertakings concerned to be adequately informed of the content of the commitments defined.

The Commission recently announced that it would proceed with the drafting of a new competition act, in order to further harmonise the national competition regulation with the EU Acquis. This will be an opportunity to address all the deficiencies identified in Article 58 of the Competition Act and enable a complete application of the commitment procedure provided for in Article 9 of the EU Regulation. It is the only way to ensure an adequate legal regime that will guarantee the efficient application of the commitment procedure in Serbia. Evidently, the Commission's practice will have to be consistent with the EU's and will have to guarantee the respect of parties' rights, transparency of proceedings and legal certainty in its procedure. 